\title{
Experimental Study on Anti Scorpion Venom potential of Paravatadi Agada of Ayurveda in Indian Red Scorpion Venom (Mesobuthus tamulus)
}

\author{
Research Article
}

Sunil Deshmukh1, Sonali Chalakh2*, Dhirajsing Rajput ${ }^{3}$

1. PG Scholar, 2. Professor, Department of Agad Tantra, 3. Associate Professor, Department of Rasashastra, Mahatma Gandhi Ayurveda College, Hospital and Research Centre, Datta Meghe Institute of Medical Sciences, Salod (H), Wardha, Maharashtra.

\begin{abstract}
Background: Scorpion sting is a frequent event in tropical and subtropical countries. The objective of this study is to evaluate Efficacy of Paravatadi Agada on Indian Red Scorpion Venom (Mesobuthus Tamulus). Materials and Methods: PA was prepared as per textual reference. Water soluble extract of PA was obtained using Soxhlet apparatus. Swiss albino mice of 20-30gm were used. Lypholised venom sample of Mesobuthus tamales and Lyophilized monovalent enzyme refined immunoglobulin anti scorpion venom serum (ASV) was used. Using lethal dose of scorpion venom $(25.12 \mu \mathrm{g} / \mathrm{g})$, venom neutralising property of PA extract $(300 \mathrm{mg} / \mathrm{kg}), \mathrm{ASV}(1 \mathrm{mg})$ intraperitoneally and PA $(31 \mathrm{mg} / \mathrm{mice})$ orally. The parameter used were Mean survival time, protection fold and percentage survival of animals over the period of $24 \mathrm{hrs}$. Histopathological examinations of all mice were done. Result: Maximum protection fold is seen in ASV treated group which is 10.03 with $83.33 \%$ survival but water soluble extract of PA also showed some protective effect against scorpion venom 7.68 with $50 \%$ survival rate. Histopathological examination showed that PA extract, ASV and PA treated group showed less effect of scorpion venom on Heart, Liver and Kidney compared to control group in which sever histopathological manifestations are detected. Conclusion: The protection fold and survival percentage of extract of PA was better than Powder form of PA but less than ASV but enough significant in view of availability, safety, ease in method of preparation and cost effectiveness compared to ASV.
\end{abstract}

Key Words: Scorpion sting, Paravatadi Agada, Indian red scorpion venom, Anti-scorpion venom.

\section{Introduction}

Scorpion sting is a frequent event in tropical and subtropical countries (1). It is estimated that in India the annual number of scorpion stings cases exceeds 1.23 million, of which over 32,250 may be fatal. India is the most affected, with a reported incidence of $0.6 \%$ (2) These are found in large quantity in western Maharashtra, Parts of Karnataka, Andhra Pradesh, Saurashtra, Pondicherry and Tamil Nadu (3). In India severe scorpion sting due to Mesobuthus tamales species of scorpion is mainly found in Kokan region (4). Higher incidence of scorpion sting occurred during hot months attributed to increase in agricultural activity $(5,6)$. Scorpion venom causes massive release of neurotransmitter which results in clinical features of envenomation (7). Clinical effects of stings are related to age, size of scorpion, season of the sting and time lapsed between sting and hospitalization (8). It is

\section{* Corresponding Author:}

\section{Sonali Chalakh}

Professor, Department of Agad Tantra, Mahatma

Gandhi Ayurveda College, Hospital and Research

Centre, Datta Meghe Institute of Medical Sciences,

Salod (H), Wardha, Maharashtra, India

Email Id:spchalakh@gmail.com classified into local manifestation, systemic involvement, Cardiogenic failure (hypotension, ventricular arrhythmia, bradycardia, cardiovascular collapse) and Respiratory failure(cyanosis, dyspnoea, pulmonary oedema) (9). In Ayurveda Vrishchika(scorpion) are considered as one of the kita which is explained under the context of Kitvishpratishedha (10). Various Agada are mentioned in classic for different poisoning cases along with it can be prescribed in the condition other than poisonous incidence. (11). Paravatadi Agada (PA) is one of the remedy mentioned in Astang Hridayam for the treatment of scorpion bite poisoning and it is narrated that this formulation is best among all other remedies to treat scorpion bite (12). However, efficacy of PA has not been scientifically proved yet. Therefore, present work was undertaken with aim to evaluate the efficacy of PA in the management of Indian Red Scorpion bite on Albino mice.

\section{Materials and Methods Collection of Raw material}

All the ingredients were procured from local market Nagpur. Paravat Shakrut was collected from Poultry farmer, Wardha. Fruit of Bijapurak was collected from Kolhapur. All the drugs were authenticated by subject expert. 


\section{Preparation of PA}

For the preparation of PA all the crude drugs were made into fine powder and sieved through 80 number mesh. Powdered ingredients were taken in equal quantity in khalvayantra and one Bhavana of Bijapurak swarasa was given.

Table: 1 Ingredient used for the preparation of formulation

\begin{tabular}{|c|c|c|c|}
\hline $\begin{array}{l}\text { Name of the } \\
\text { ingredient }\end{array}$ & $\begin{array}{l}\text { Latin Name/ } \\
\text { English name }\end{array}$ & $\begin{array}{l}\text { Part } \\
\text { used }\end{array}$ & Quantity \\
\hline Tagar & $\begin{array}{l}\text { Veleriana } \\
\text { Wallichi DC }\end{array}$ & Root & $150 \mathrm{gm}$ \\
\hline Haritaki & $\begin{array}{c}\text { Terminallia } \\
\text { Chebula Retz. }\end{array}$ & Fruit & $150 \mathrm{gm}$ \\
\hline $\begin{array}{l}\text { Vishwabhaish } \\
\text { ajyam }\end{array}$ & $\begin{array}{l}\text { Zingiber } \\
\text { Officinale } \\
\text { Rosc. }\end{array}$ & Root & $150 \mathrm{gm}$ \\
\hline $\begin{array}{l}\text { Bijapurak } \\
\text { Swaras }\end{array}$ & $\begin{array}{c}\text { Juice Of Citrus } \\
\text { Medica L. }\end{array}$ & Fruit & $150 \mathrm{gm}$ \\
\hline $\begin{array}{l}\text { Parawat } \\
\text { shakrut } \\
\text { (pigeon } \\
\text { droppings) }\end{array}$ & \multicolumn{2}{|c|}{ Pigeon droppings } & 1 lit \\
\hline
\end{tabular}

\section{Preparation of extract of PA}

Water soluble extract was prepared according to the procedure reported by Mahanta and Mukharjee by using Soxhlet apparatus(13). $50 \mathrm{gm}$ of PA taken in 'timble' made of porous cotton bag, is placed in central part and $500 \mathrm{ml}$ water taken in solvent flask and heated it on $60^{\circ} \mathrm{C}$ to $70^{\circ} \mathrm{C}$ temperature. To allow proper soaking for better extraction, the mixture was kept for 2 hours. After 2 hour of heating the liquid in solvent flask was boiled at $100{ }^{\circ} \mathrm{C}$, during heating the vapors were condensed in condenser. The condensed extract drips into the timble containing the Paravtadi Agada, extracting it by contact. When the level of liquid in this rises to the top of the siphon tube, the liquid contents of central part was run through siphon into Solvent flask. This process was carried out until a drop of solvent from the siphon tube does not leave residue when evaporated which was observed after continuing the process for five times. The extract thus obtained was dark brown in colour. Then the extract was collected and heated on gas stove at $60{ }^{\circ} \mathrm{C}$ till the liquid attained semisolid type consistency and then the heating process was stopped. The extract was taken into Petri dish and dried in oven. The dried extract was dried and powdered and packed into airtight bottle.

\section{Scorpion Venom sample}

Lyophilized venom sample of Mesobuthus tamulus was purchased from Haffkine Institute, Parel, Mumbai, Maharashtra and was stored at $2-8^{\circ} \mathrm{C}$ for future use, taking all necessary precautionary measures of handling and storage.

\section{Antiscorpion venom sample (ASV)}

Lyophilized monovalent enzyme refined immunoglobulin ASV of Mesobuthus tamulus was purchased from Haffkine Bio-pharmaceutical
Corporation Ltd., Parel, Mumbai, Maharashtra and stored at $2-8^{\circ} \mathrm{C}$ for future use, taking all necessary precautionary measures of handling and storage. Each 1 $\mathrm{ml}$ of reconstituted ASV neutralizes not less than $1.0 \mathrm{mg}$ of dried red scorpion venom.

\section{Experimental Animals}

Swiss albino mice of either sex weighing 20-30 $\mathrm{g}$ were used for the study. They were procured from the animal house of Datta Meghe Institute of Medical sciences, Wardha, Maharashtra. All the animals were kept under standard condition of $25 \pm 2^{\circ} \mathrm{C}$ and relative humidity $50+60 \%$.All animals had free access to standard chow and water ad libitum. All Animals were acclimatized to laboratory conditions for 7 days before the start of the study. All the experimental protocol were approved by Institutional Animal Ethics Commitee (IAEC) with approval no. DMIMSDU/ IAEC/ 2015-16/006 and performed according to CPCSEA guidelines for care and use of animals. Dose of PA was calculated as per conversion of human dose to experimental animal dose (14).

\section{Acute toxicity of Red Scorpion Venom and its neutralisation by PA}

The animals were divided into four groups, each containing six animals. Each animal in all groups were administered $\mathrm{LD}_{99}$ dose of Mesobuthus tamulus venom $(25.12 \mu \mathrm{g} / \mathrm{g})(15)$ (Intraperitoneally). Group 1 received Distilled water $(0.5 \mathrm{ml})$ intraperitoneally and was considered as control group. Group 2 received Extract of Paravatadi Agada $(300 \mathrm{mg} / \mathrm{kg})$ intraperitoneally (PA I) and was considered as Test group-1. Group 3 received ASV $(1.0 \mathrm{mg})$ intraperitoneally and was considered as standard group. Group 4 received Paravatadi Agada ( $31 \mathrm{mg} /$ Mice) orally (PA II) and was considered as Test Group-2. All the groups received the same volume of preparation. In all the groups, duration of survival time, protection fold and percentage survival animals over the period of $24 \mathrm{hr}$ were the parameters used.

\section{Histopathological Examination}

After Assessing the Survival period up to 24 hour, Survival animals were chloroform anesthetised . All animals were slaughtered and dissected. The Heart, livers, kidneys were collected immediately in order to avoid diagnosis error and placed in formalin ( $10 \%$ formaldehyde in water) as fixative solution. All samples were collected and send to the Histopathogy department for histopathological examination.

\section{Statistical analysis}

The statistical analysis was done using unpaired student's $\mathrm{t}$ test. $\mathrm{P}<0.0106$ was considered statistically significant

\section{Observation and result}

Statistical analysis depicted in Table I indicates that Group II (PA I) showed statistically significant result in compared to Control group ( $\mathrm{P}$ value 0.005).Similarly Group III (ASV) \& Group IV (PAII) 
also showed significant difference in comparison to control group $(<0.001$ and 0.030 respectively). Table 1 , 2,3 . When group III was compared with Group II (PA I) and Group IV (PAII) then obtained nonsignificant statistical difference indicating that both Group II and Group IV are almost as effective as ASV. (Table 4,5,6). Maximum protection is found in ASV treated group (Group III) as compared to test group (Group II and IV) and control group (Group I) but Percentage of survival is $50 \%$ in both the test group which is nearly equal to ASV group (83.33\%). (Table 7)

Twenty-four Mice were used for histological studies; the animals were divided into 4 groups. Mice in control group shows significant changes such as Myolysis \& necrosis in Heart, congestion of portal vein, loss of hepatocytes, acute Haemorrhages in liver and interstitial oedema in kidney. Histopathological study of group I (control) showed significant changes in heart, liver and kidney which are almost complete toxic manifestation of scorpion venom. Pathological manifestations observed in control group such as Myolysis \& Necrosis in heart, Congestion of portal/ central veins, Loss of Hepatocytes, Acute Haemorrhages in Liver and Interstitial oedema in kidney are detected which suggest the intense poisonous effect scorpion venom. In Test group I, where PA extract is used the changes observed in heart, liver and kidney are less. In third group which was standard also the pathological changes was seen in Heart and liver while the kidney is observed almost normal that means ASV is not $100 \%$ effective in preventing effect of poison. In Test group II which was treated by PA few pathological changes such as oedema, inflammation and acute haemorrhage in Heart detected but Vascularity of Heart remains normal which indicate cardioprotective action while Acute Haemorrhages and Inflammatory cell infiltrate are also found in Liver and Mild toxic pathological changes are also observed in Kidney.

Table 1: Comparison of survival time between I \& II

\begin{tabular}{|c|c|c|c|c|c|c|c|}
\hline Group Name & Intervention & Mean & Std Dev & SEM & Difference & P value & t Value \\
\hline Group I & Distilled water (DW) & 121.333 & 48.743 & 19.899 & & & \\
Group II & $\begin{array}{c}\text { Extract of Paravatadi Agada } \\
\text { (300 mg/kg) PA1 }\end{array}$ & 933 & 558.282 & 227.918 & 811.667 & 0.005 & 3.548 \\
\hline
\end{tabular}

Table 2: Comparison of survival time between I \& III

\begin{tabular}{|c|c|c|c|c|c|c|c|}
\hline Group Name & N & Mean & Std Dev & SEM & Difference & P value & t Value \\
\hline Group I & 6 & 121.333 & 48.743 & 19.899 & 1096.500 & $<0.001$ & 4.916 \\
\hline Group III & 6 & 1217.833 & 544.195 & 222.167 & & &
\end{tabular}

Table 3: Comparison of survival time between I \& IV

\begin{tabular}{|c|c|c|c|c|c|c|c|}
\hline Group Name & N & Mean & Std Dev & SEM & Difference & P value & t Value \\
\hline Group I & 6 & 121.333 & 48.743 & 19.899 & 699.667 & 0.03 & 2.520 \\
\hline Group IV & 6 & 821 & 678.241 & 276.891 & & & \\
\hline
\end{tabular}

Table 4: Comparison of survival time between II \& III

\begin{tabular}{|c|c|c|c|c|c|c|c|}
\hline Group Name & N & Mean & Std Dev & SEM & Difference & P value & t Value \\
\hline Group II & 6 & 933 & 558.282 & 227.918 & 284.833 & 0.392 & 0.895 \\
\hline Group III & 6 & 1217.833 & 544.195 & 222.167 & & \\
\hline
\end{tabular}

Table 5: Comparison of survival time between II \& IV

\begin{tabular}{|c|c|c|c|c|c|c|c|}
\hline Group Name & N & Mean & Std Dev & SEM & Difference & P value & t Value \\
\hline Group II & 6 & 933 & 558.282 & 227.918 & 112.000 & 0.761 & 0.312 \\
\hline Group IV & 6 & 821 & 678.241 & 276.891 & & \\
\hline
\end{tabular}

Table 6: Comparison of survival time between III \& IV

\begin{tabular}{|c|c|c|c|c|c|c|c|}
\hline Group Name & N & Mean & Std Dev & SEM & Difference & P value & t Value \\
\hline Group III & 6 & 1217.833 & 544.195 & 222.167 & 396.833 & 0.29 & 1.118 \\
\hline Group IV & 6 & 821 & 678.241 & 276.891 & & & \\
\hline
\end{tabular}

Table 7: Protection fold, Survival animals and Survival percentage against $\mathrm{LD}_{99}$ of the red scorpion venom

\begin{tabular}{|c|c|c|c|}
\hline Group (N=6) & Protection Fold & $\begin{array}{c}\text { Total animals survived/total animals in } \\
\text { each group }\end{array}$ & \% of survival \\
\hline Group - I & - & $0 / 6$ & $0 \%$ \\
\hline Group - II & 7.68 & $3 / 6$ & $50 \%$ \\
\hline Group - III & 10.03 & $5 / 6$ & $83.33 \%$ \\
\hline Group - IV & 6.76 & $3 / 6$ & $50 \%$ \\
\hline
\end{tabular}


Discussion

Indian Red Scorpion (Mesobuthus tamulus) belonging to Buthidae family is the most lethal amongst all the poisonous species of scorpions in India. Scorpion venom is a potent sodium channel activator. It causes, delay in closing of neuronal sodium channels, which results in "autonomic storm" leading to sudden pouring of endogenous catecholamine's into circulation leading to transient sympathetic and parasympathetic stimulation (16) .In India since 1997Antiscorpion venom is available for scorpion sting (17).Various studies conducted shows that $1 \mathrm{ml}$ of reconstituted ASV serum neutralized $1.2 \mathrm{mg}$ of Indian red scorpion venom by IV route in vivo study in mice (18).

In the present study when $\mathrm{LD}_{99}$ of Scorpion venom is injected observed mean survival time (in minutes) in group I, II, III and IV is $121.333 \pm 48.743$, $933.000 \pm 558.282,1217.833 \pm 544.195$ and $821.000 \pm$ 678.241 respectively. Mean survival time of PAI extract treated group (Group II) is considerably nearer to ASV treated group means ASV and PA extract treated group showed significant scorpion venom neutralizing action. However, this action is detected less in PAII group. (group IV)

The ingredients of Paravatadi Agada have the necessary actions which are needed in treating scorpion bite. Haritaki is Rasayana, Balya, Vayasthapana, Ayusya, Sarvaroga prasamana, Anulomana, Grahi, Medya, Hridya, Deepana, Chakshushya, Medohara. (19)It works as Stomachic, Tonic, Carminative, Expectorant, Laxative, Astringent, Good in eye diseases, Disease of heart and the bladder.(20) It has Cardio- protective, Wound healing, Hepatoprotective activity.(21,22,23) Tagara is Vataghna and Tridoshahara.(24) It is useful in treating anxiety, breathlessness, epilepsy, giddiness and fainting fits. The herb lowers blood pressure, palpitation of the heart and even strengthens the heart. It proves helpful in treating head congestion and loosens phlegm in different cough and lung congestion.(25) It have Analgesic, Anti inflammatory and Antioxidant activity. $(26,27)$ Sunthi is Anulomana, Pachana, Dipana, Vatakaphahara, Bhedana, Hrudya, Svarya.(28) It is used in the prophylaxis of nausea and vomiting associated with motion sickness, Dyspepsia, flatulence, seasickness and as a narcotic antagonist, and as an anti -inflammatory agent in the treatment of migraine headache and rheumatic and muscular disorders. $(29,30,31,32)$ Bijapur Nimbu is Kanha Sodhaka, Chardigrahan, Dipana, Hridya, Jihvasodhaka, Kaphahara, Medhya, Pittahara, Vatahara.(33) It has Analgesic and Cardioprotective activity. $(34,35)$ Paravat Shakrut is Kaphapittashamak and Raktapittashamaka.(36)

Histopathological study of group I (control) showed significant changes in heart, liver and kidney which are almost complete toxic manifestation of scorpion venom. Pathological manifestations observed in control group such as Myolysis \& Necrosis in heart, Congestion of portal/central veins, Loss of Hepatocytes, Acute Haemorrhages in Liver and Interstitial oedema in kidney are detected which suggest the intense poisonous effect scorpion venom. [Figure 1 (1.1 to 1.6)]
In Group- II pathological changes in Heart such as Oedema, Myolysis \& Necrosis, Inflammation and Acute Haemorrhages are evident from histopathological findings. In this group, Liver of four animals showed Congestion of portal/central veins \&sinuses; Loss \& Necrosis of Hepatocytes (Toxic necrosis); Acute Haemorrhages and Inflammatory cell infiltrate which can be considered as toxic effect of scorpion venom. Rare hyperaemia in Kidney due to changes within glomeruli, focally positive changes within Tubules including Ischemic necrosis \& Tubule cell swelling and Infiltrate of leucocytes $\&$ eosinophils are also detected in histopathological study of Kidney of this group. In comparison to control group, the changes observed in Heart, Liver and Kidney are enough to suggest that extract of Paravatadi Agad have considerable positive effect of scorpion venom. [Figure 2 (2.1 to 2.6)]

In Group- III (Standard Group) ASV was administered which is standard line of management of scorpion bite. However, few pathological changes are detected in Heart, Liver and Kidney especially in S5. The reason is unknown but compared to heart and liver, the changes observed in Kidney are almost normal. This may be due the less pharmacological action of scorpion on Kidney as most of the concentration of scorpion venom gets absorbed while passing through Heart and Liver. Still the pathological finding in Heart and Liver suggests that ASV is not $100 \%$ effective in preventing effect of scorpion venom. [Figure 3 (3.1 to 3.6)]

Group- IV was treated with Paravatadi Agada. Few pathological changes such as oedema, Inflammation and Acute Haemorrhages in Heart are detected in histopathological study of few animals. However Vascularity of heart remains normal which indicate cardio-protective action but the range of this action seems limited. Similarly, Congestion of portal/ central veins \& sinuses, Loss of Hepatocytes (Toxic necrosis), Acute Haemorrhages and Inflammatory cell infiltrate are also found in Liver of Paravatadi Agada treated group. Mild toxic pathological changes are also observed in Kidney. [Figure 4 (4.1 to 4.6)]

Hence it can be concluded that ASV as well as PA extract and PA have scorpion venom neutralizing action. However, in findings of present study ASV is said to be have better efficacy than both PA and PA extract it is also observed that PA extract has better effect than PA. This may be due to fine constituent and low molecular chemicals present in extract which are not in more proportion in powder form.

As experimental animal studies have limitations such as the pharmacodynamic and pharmacokinetic of medicine may vary in human compared to animal. More importantly Ayurveda way of treating is based on individual personality assessment (which is known as Prakruti) as well as thorough following specific dietary guidelines. These dietary guidelines are helpful in influencing drug action as well as in reducing the effect of etiological factors.(37) Here it can be claimed that the observed less but significant effect of PV extract compared ASV can be further improved with dietary regimen or administration of other similar formulation having anti-scorpion venom action. However, further 
studies are required to access the precision in aforementioned claim.

\section{Conclusion}

The protection fold and survival percentage of PA extract $(7.68 \%$ and $50 \%$ respectively) are enough significant in view of availability, compared to ASV which have protection fold 10.03 and survival percentage 83.33. Extract of PA is better effective than powder form of PA but it is comparatively less effective than ASV. Therefore, based on the observed effect, extract of PA can also be utilized in case red scorpion bite, however further repetition of similar work by increasing concentration of extract may provide more valid and applicable outcome.

\section{Reference}

1. Santhanakrishnan BR, RangnathanG, Ananthasubramanian P. Cardiovascular manifestation of scorpion stings in children. Indian Pediatrics 1977; 353-356.

2. Chippaux JP, Goyffon M. Epidemiology of scorpionism: a global appraisal. Acta tropica. 2008:1;107(2):71-9.

3. Maled V, Dixit U. Profile of scorpion envenomation in Rural India. Journal of Indian Academy of Forensic Medicine. 2016;38(4):446-8.

4. Bawaskar HS, Bawaskar PH. Treatment of envenoming by Mesobuthus tamulus (Indian red scorpion). Transactions of the Royal Society of Tropical Medicine and Hygiene. 1992:1;86(4):459-.

5. Bawaskar HS. Scorpion Sting: Clinical Manifestations, Management, and Literature. Popular Prakashan; 1999, p.120

6. Bawaskar HS and Bawaskar PH. Indian scorpion envenoming. Indian J Pediatr 1998;65:383-91.

7. Natu VS, Kamerkar SB, Geeta K, Vidya K, Natu V, Sane S, Kushte R, Thatte S, Uchil DA, Rege NN, Bapat RD. Efficacy of anti-scorpion venom serum over prazosin in the management of severe scorpion envenomation. Journal of postgraduate medicine. 2010:1;56(4):275.

8. Ouanes -Basbes 1, Elatrous S, Aubrey N, Eiayeb M and Abroug F. Direct vs mediated effects of scorpion venom : an experimental study of the effects of second challenge with scorpion venom. Intensive Care Medicine 2005;31:441-46.

9. Khattabi A oulaymani -Bancheikh $\mathrm{R}$ et al. Classification of clinical consequences of scorpion sting: consensus development. Trans Roy Soc Trop Med Hyg 2011;105:364-69.

10. Upadhya Y. Ashtang Hridaya of Acharya Vagbhat. $1^{\text {st }}$ edition.Varanasi; Chaukhamba Sanskrit Sansthan ; Reprint 2005:587

11. Sonare K. Chalakh S. Phytochemical Evaluation of Maha Agada; ayurpub; 2019:4(4):1279-1285

12. Upadhya Y. Ashtang Hridaya of Acharya Vagbhat.1 ${ }^{\text {st }}$ edition.Varanasi; Chaukhamba Sanskrit Sansthan ; Reprint 2005:588, p. 224

13. Mahanta M, Mukharjee AK. Neutralization of lethality, myotoxicty and toxic enzymes of Naja kaouthia venom by Mimosa pudica root extracts. J Ethnopharmacol 2001;75:55-60

14. Paget GE, Barnes JM. Evaluation of Drug activities. In: Lawrence DR, Bacharach AL, editors. Pharmacometrics.Vol. 1. New York: Academic Press; 1969: p. 161.

15. Brahmane RI, Pathak SS, Wanmali VV, Salwe KJ, Premendran SJ, Shinde BB. Partial in vitro and in vivo red scorpion venom neutralization activity of Andrographispaniculata. Pharmacognosy Res. 2011;3: 44-8.

16. Kankonkar RC, Kulkurni DG, Hulikavi CB. Preparation of a potent anti-scorpion-venom-serum against the venom of red scorpion (Buthus tamalus). Journal of postgraduate medicine. 1998:1;44(4):85.

17. Vasconcelos F, Lanchote VL, Bendhack LM, Giglio JR, Sampaio SV, Arantes EC. Effects of voltagegated $\mathrm{Na}+$ channel toxins from Tityusserrulatus venom on rat arterial blood pressure and plasma catecholamines. Comp BiochemPhysiol C ToxicolPharmacol. 2005;141:85-92.

18. Kankonkar RC, Kulkurni DG, Hulikavi CB. Preparation of a potent anti-scorpion-venom-serum against the venom of red scorpion (Buthus tamalus). Journal of postgraduate medicine. 1998:1;44(4):85.

19. Dodke PC, Pansare TA. Ayurvedic and Modern aspect of Terminalia chebula Retz. Haritaki An Overview. International Journal of Ayurvedic and Herbal Medicine. 2017;7(2):2508-17.

20. Amalraj A, Gopi S. Medicinal properties of Terminalia arjuna (Roxb.) Wight \& Arn.: a review. Journal of traditional and complementary medicine. 2017:1;7(1):65-78.

21. Tasduq SA, Singh K, Satti NK, Gupta DK, Suri KA, Johri RK. Terminalia chebula (fruit) prevents liver toxicity caused by sub-chronic administration of rifampicin, isoniazid and pyrazinamide in combination. Human \& experimental toxicology. 2006;25(3):111-8.

22. Riaz M, Asghar A, Rashid R, Shahzad-ul-Hussan S. Treasures hunt in old mines: Terminalia chebulaBased traditional herbal medicinal products. The Natural Products Journal. 2015 Dec 1;5(4):252-67.

23. Suchalatha S \& Shyamala CS, Protective effect of Terminalia chebula against experimental myocardial injury induced by isoproterenol, Indian Journal of Experimental Biology, 2004;42: 174-8

24. Vaidya B.G; Nighantu Adarsha Vol.I;Chaukhamba Bharati Academy Varanashi; Reprint 2007:551-553.

25. Lavekar G.S; Databese on medicinal plant used in Ayurveda and Siddha; Central council for research in Ayurved and Siddha, Department of Ayush ministry of health and family welfare Government of India. Vol.8: 2008, p.445

26. Sah S P, Mathela C M and Chopra K. Elucidation of possible mechanism of analgesic action of Valeriana wallichii D C. (Patchouli alcohol) in experimental animal models. Indian Journal of Experimental Biology, 2010;48(3):289-293.

27. Khuda F, Iqbal Z, Zakiullah, Khan A, Nasir F. Antimicrobial and anti- inflammatory activities of leaf extracts of Valeriana wallichii D C. Pakistan 
Sunil Deshmukh et.al., Anti Scorpion Venom potential of Paravatadi Agada of Ayurveda in Indian Red Scorpion Venom Journal of Pharmaceutical Sciences, 2013; 26(3): $451-4$

28. Sharma P.; Dravyaguna Vigyan; Chaukhamba Bharati Academy Varanasi; Volume-II; Reprint 2005, p.331

29. Kiuchi F, Iwakami S, Shibuya M, Hanaoka F, Sankawa U. Inhibition of prostaglandin and leukotriene biosynthesis by gingerols and diarylheptanoids. Chemical and Pharmaceutical Bulletin. 1992:25;40(2):387-91.

30. Nurtjahja-Tjendraputra E, Ammit AJ, Roufogalis BD, Tran VH, Duke CC. Effective anti-platelet and COX-1 enzyme inhibitors from pungent constituents of ginger. Thrombosis research. 2003:1;111(4-5):259-65.

31. Sharaky AS, Newairy AA, Kamel MA, Eweda S; Protective effect of ginger extract against bromobenzene-induced hepatotoxicity in male rats.; Food Chem Toxicol, 2009:47(7):1584-1590.

32. Kim HW, Murakami A, Abe M, Ozawa Y, Morimitsu Y, Williams MV, Ohigashi H.; Suppressive effects of mioga ginger and ginger constituents on reactive oxygen and nitrogen species generation, and the of inducible proinflammatory genes in macrophages.; Antioxid Redox Signal; 2005:7:1621-1629.

33. Lavekar G.S; Databese on medicinal plant used in ayueveda and siddha; Central council for research in Ayurved and siddha, Department of Ayush ministry of health and family welfare Government of India. 2008, p. 118

34. Negi A.; Analgesic activity of fruit decoction of Citrus medica Linn.; Journal of Pharmacy Research; 2010;3(9):2119-21

35. Joshi AI, Tirgar PR. Evaluation of cardiotonic effect of Citrus medica in congestive heart failure; An international journal of pharmaceutical sciences; 2013; 4(4): 1-10.

36. Yadavji Trikamaji V. Charaksamhita of Agnivesha of Charaka \& Dhdudhbala with Ayurveda Dipika commentary by Chakrapanidatta.Reprint.Varanasi; Chaukhamba Surbharati Prakashan; 2008. p.432

37. Rajput D, Patgiri B. Ayurvedic view on heavy metal poisoning with special reference to Naga bhasma incinerated lead, a literary study. Int J Pharm Biol Arch. 2013;4(1):41-5. 
Figure 1: Histopathological study of group- i (control group)

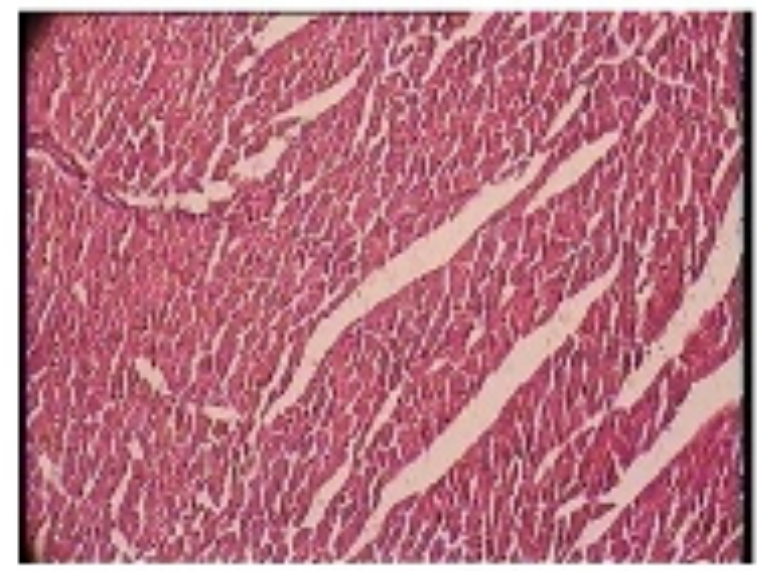

Fig. 1.1: Heart $(200 \mathrm{X})$

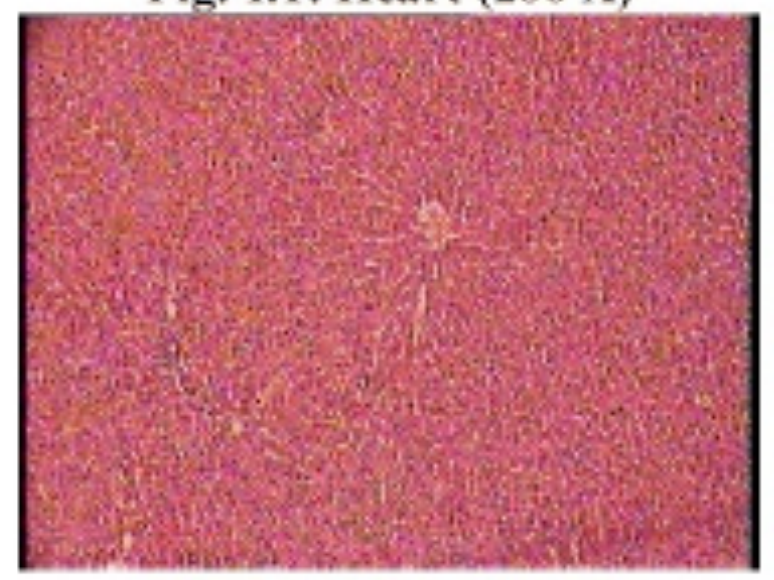

Fig. 1.3: Liver (200 X)

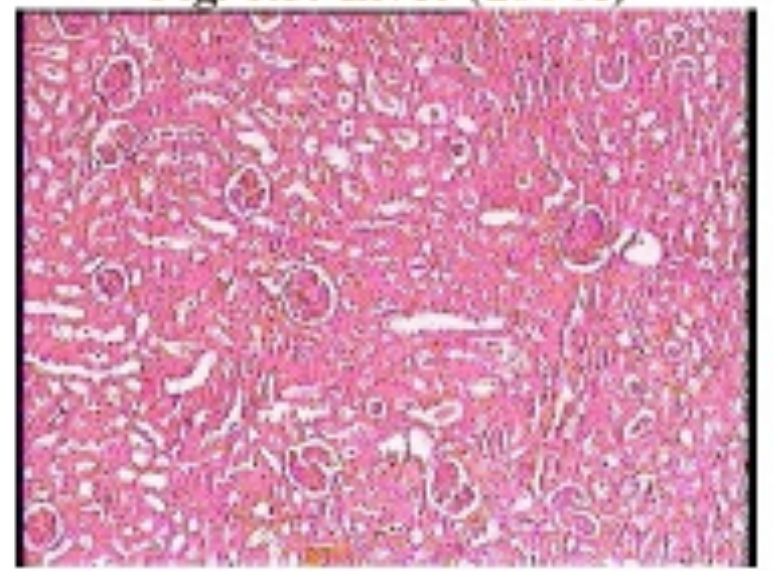

Fig. 1.5: Kidney $(200 \mathrm{X})$

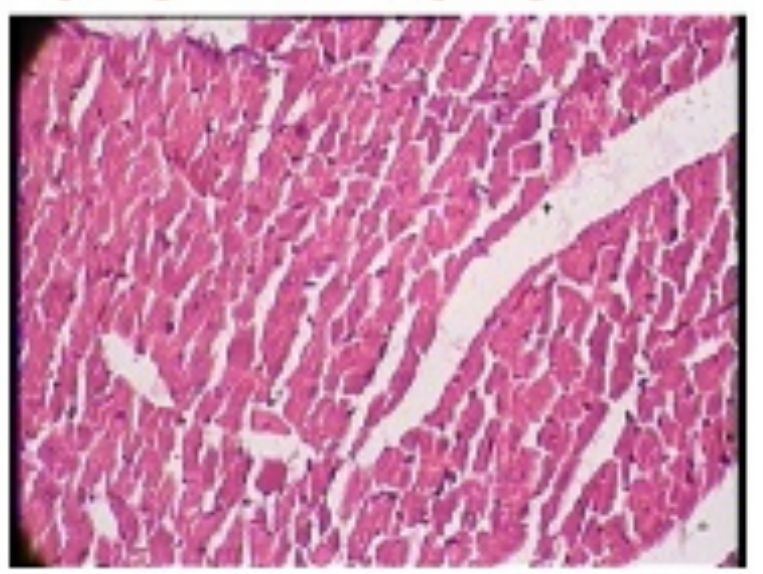

Fig. 1.2: Heart $(400 \mathrm{X})$

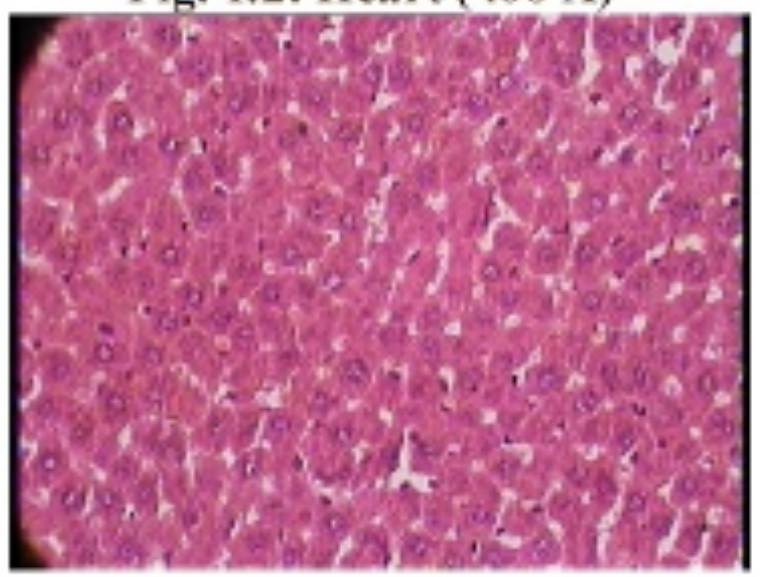

Fig. 1.4: Liver (400 X)

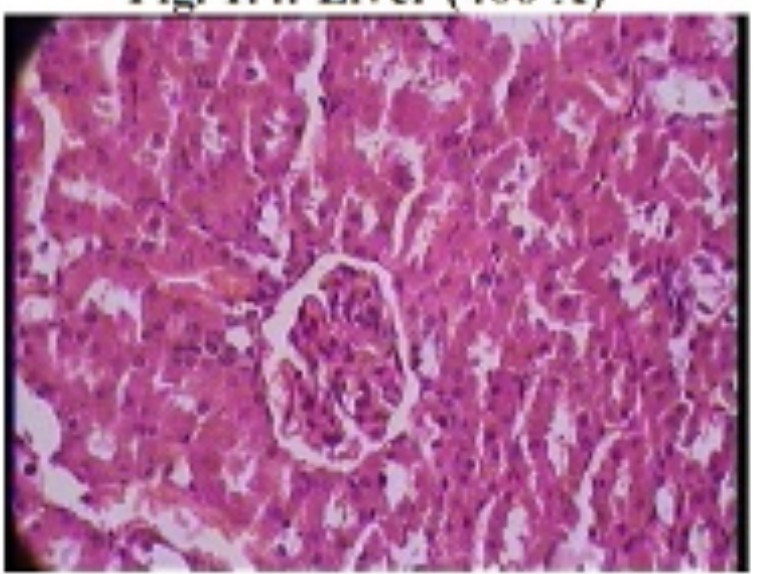

Fig. 1.6: Kidney $(400 \mathrm{X})$ 
Figure 2: Histopathological study of group- 2 (test group 1)

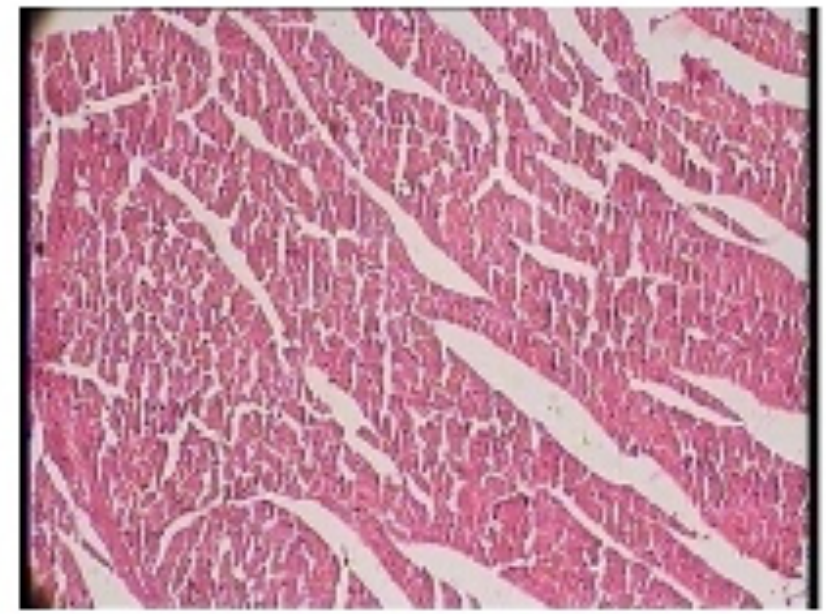

Fig. 2.1: Heart $(200 \mathrm{X})$

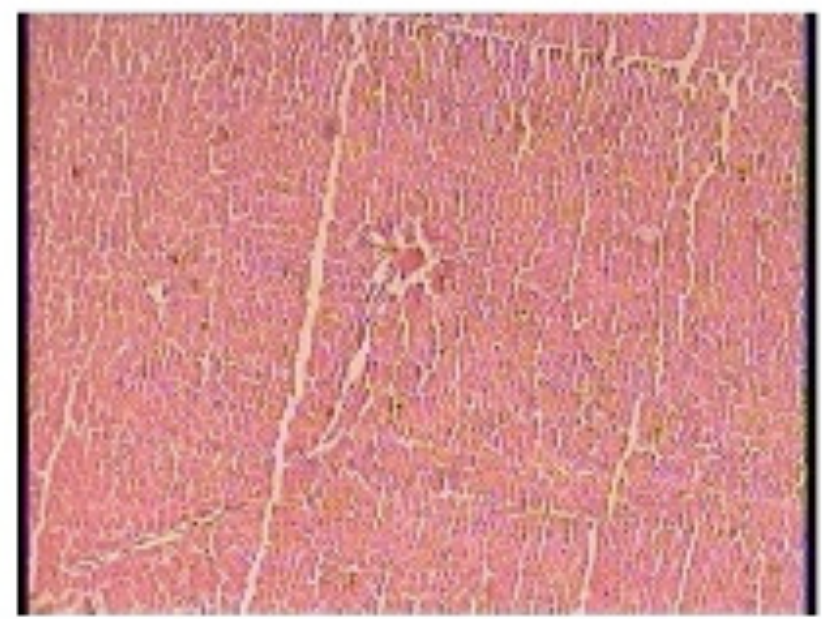

Fig. 2.3: Liver (200 X)

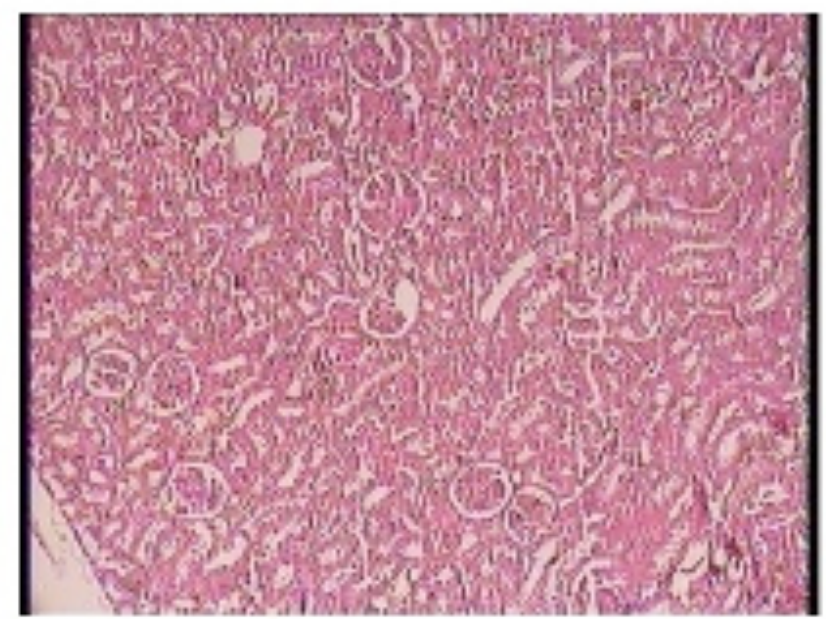

Fig. 2.5: Kidney $(200 \mathrm{X})$

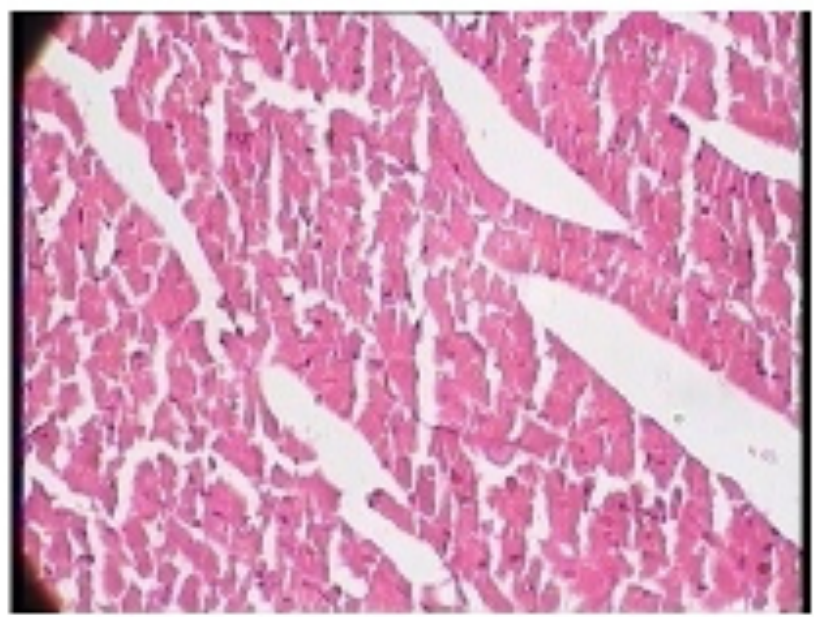

Fig. 2.2: Heart $(400 \mathrm{X})$

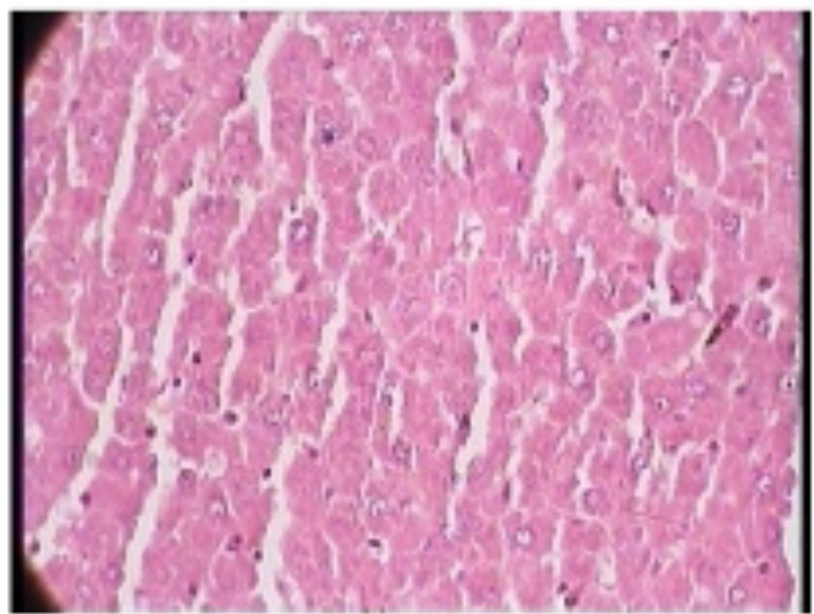

Fig. 2.4: Liver (400 X)

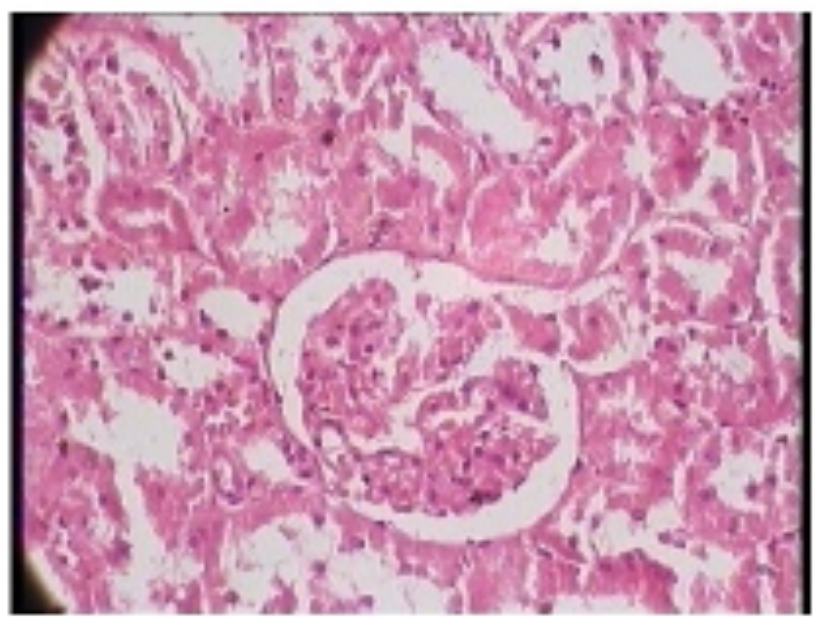

Fig. 2.6: Kidney $(400 \mathrm{X})$ 
Figure 3: Histopathological study of group- 3 (standard group)

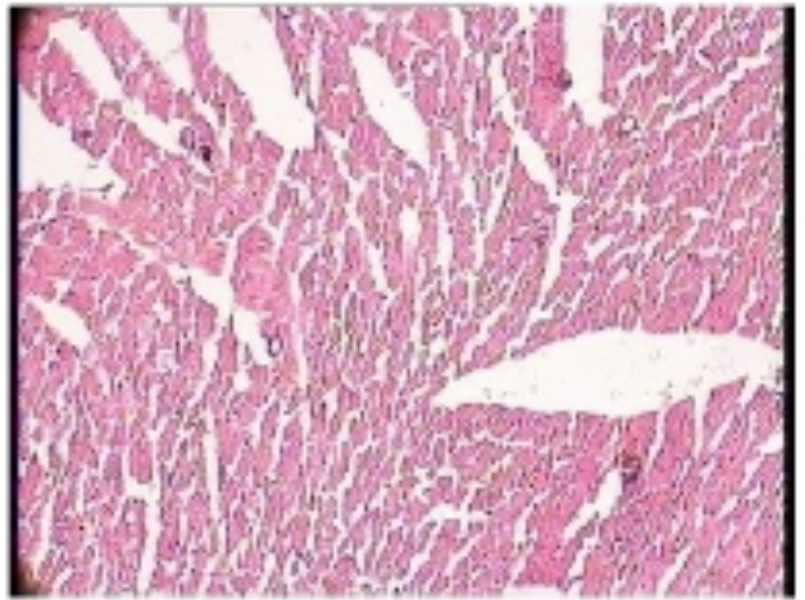

Fig. 3.1: Heart (200 X)

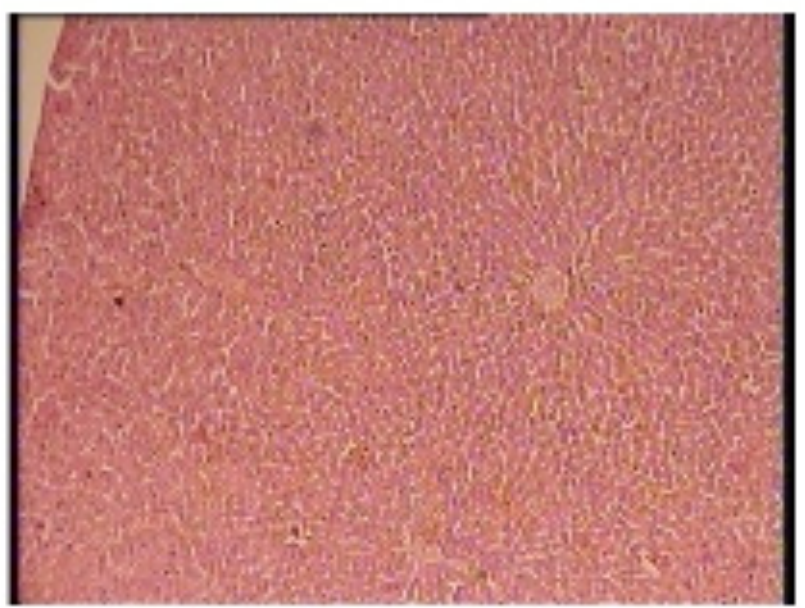

Fig. 3.3: Liver $(200 \mathrm{X})$

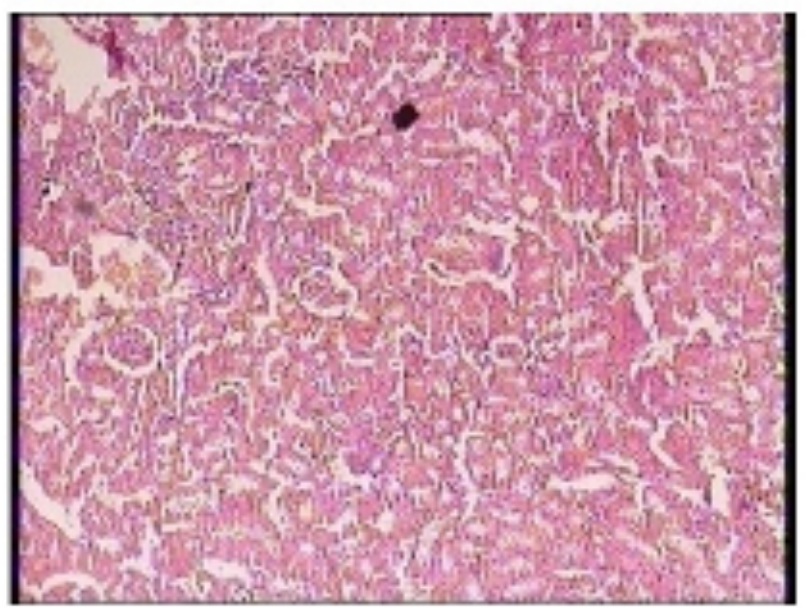

Fig. 3.5: Kidney $(200 \mathrm{X})$

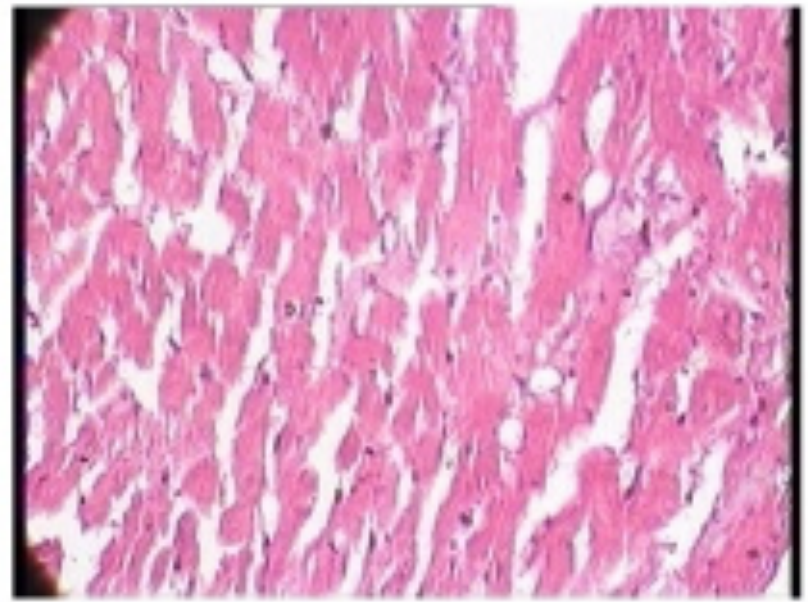

Fig. 3.2: Heart $(400 \mathrm{X})$

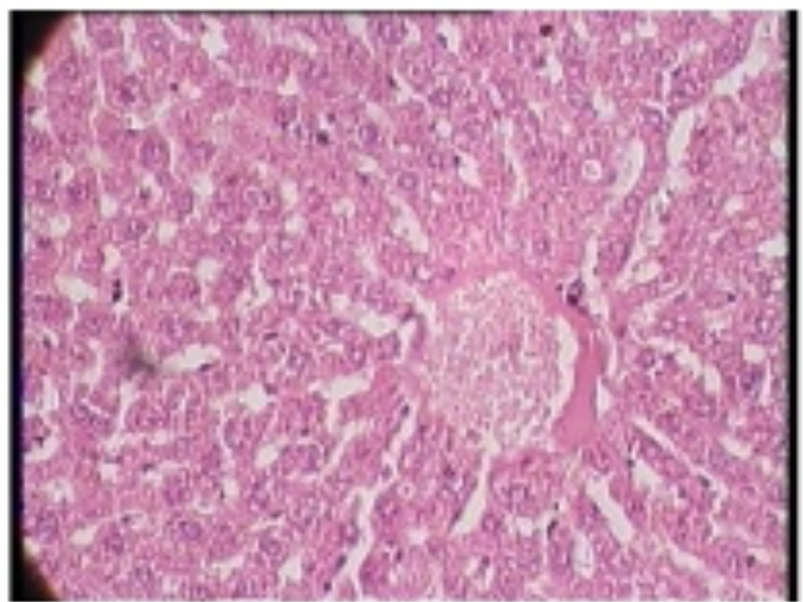

Fig. 3,4: Liver $(400 \mathrm{X})$

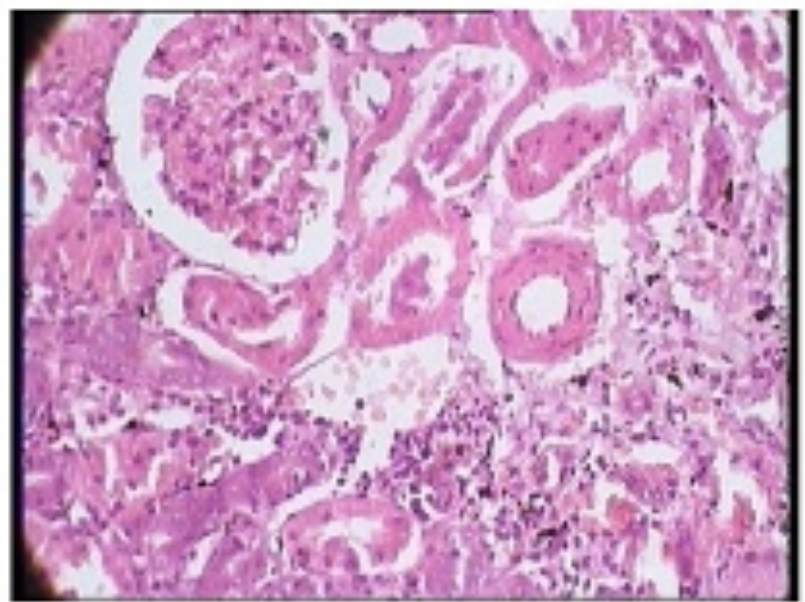

Fig. 3.6: Kidney $(400 \mathrm{X})$ 
Sunil Deshmukh et.al., Anti Scorpion Venom potential of Paravatadi Agada of Ayurveda in Indian Red Scorpion Venom

Figure 4: Histopathological study of of group- 4 (test group 2)

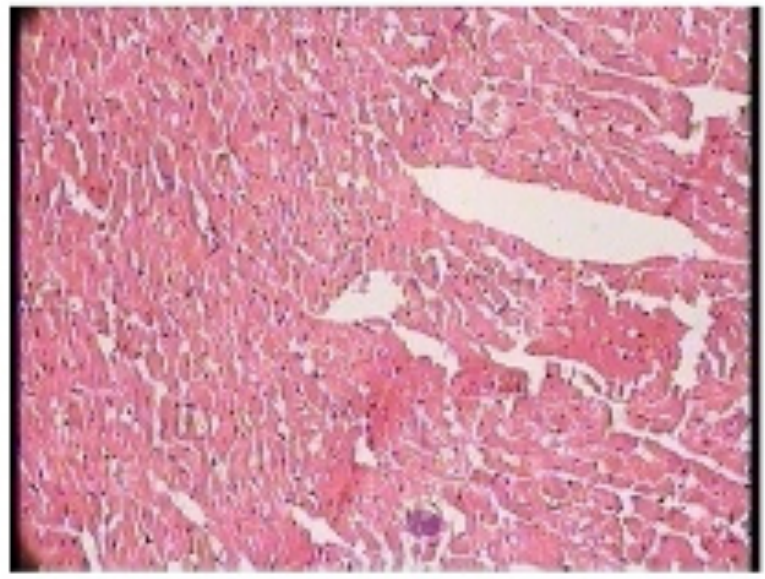

Fig. 4.1: Heart $(200 \mathrm{X})$

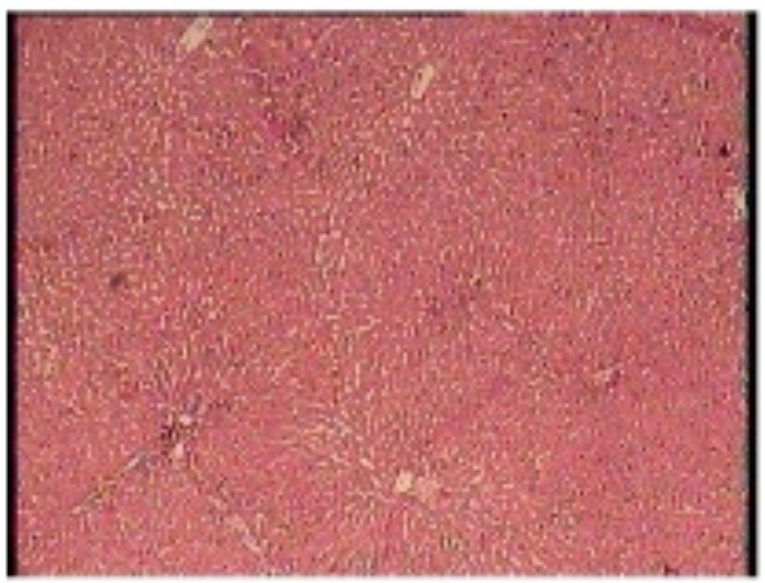

Fig. 4.3: Liver $(200 \mathrm{X})$

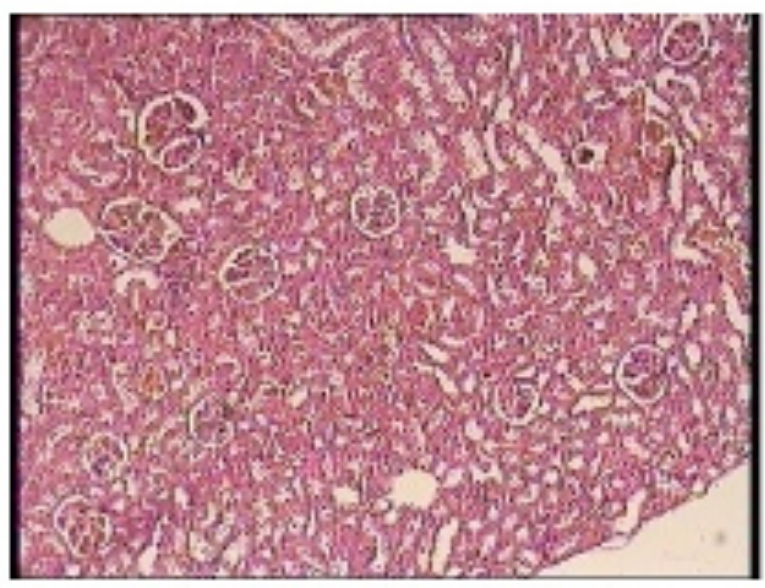

Fig. 4.5: Kidney $(200 \mathrm{X})$

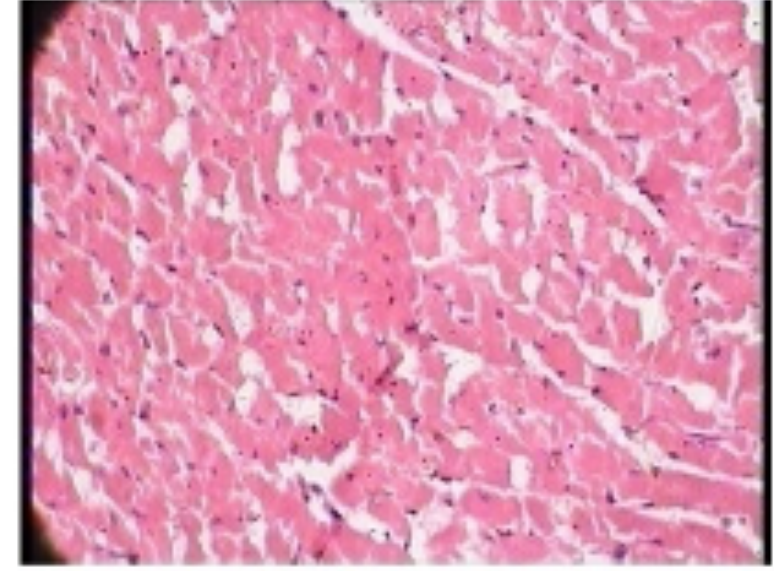

Fig. 4.2: Heart $(400 \mathrm{X})$

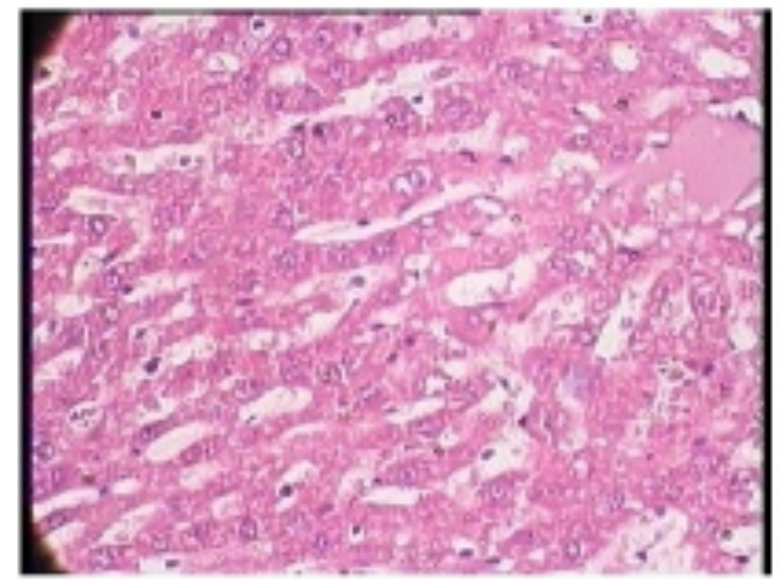

Fig. 4.4: Liver (400 X)

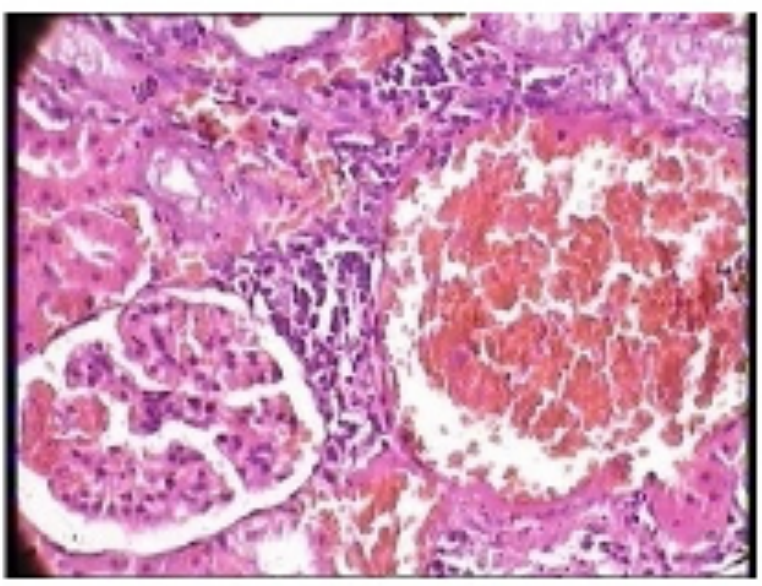

Fig. 4.6: Kidney $(400 \mathrm{X})$ 